\title{
PENGGUNAAN PLASTIK WRAP SEBAGAI PENGGANTI PARAFILM UNTUK PEMERIKSAAN BAKTERI COLIFORM PADA PRAKTIKUM MIKROBIOLOGI LINGKUNGAN
}

\author{
Nurhasmi ${ }^{1}$ \\ ${ }^{\text {I} A n a l i s ~ L a b o r a t o r i u m ~ J u r u s a n ~ T e k n i k ~ L i n g k u n g a n ~}$ \\ Fakultas Teknik Universitas Andalas \\ email;imsahrun.emi@gmail.com
}

\begin{abstract}
Abstrak
Penelitian ini bertujuan untuk mengetahui pemakaian plastik wrap sebagai pengganti parafilm pada praktikum Mikrobiologi Lingkungan untuk uji bakteri coliform secara bakteriologis terhadap air minum. Penelitian ini menggunakan air minum isi ulang pada depot air minum.Salah satu bahan yang digunakan untuk pemeriksaan ini yaitu parafilm yang berfungsi untuk menutup tabung reaksi agar cairan yang ada dalam tabung tidak tumpah sewaktu menghomogenkan cairan, dengan cara membolak balikkan tabung. Setelah proses selesai, parafilm dibuka kembali dan dibuang. Perbandingan dengan parafilm adalah ketersediaan dan harga plastik wrap dilapangan lebih mudah didapatkan dan murah. Hasil penelitian pada uji pendugaan terhadap sampel didapatkan coliform dengan jumlah yang sama dengan memakai parafilm ataupun plastik wrap yaitu 3 koloni / $100 \mathrm{ml}$. Hasil uji kepastian didapatkan jumlah bakteri 0 koloni /100 ml. Kelebihan yang didapatkan jika menggunakan plastik wrap ini yakni efisiensi biaya. Dengan menggunakan plastik wrap ini peneliti yang melakukan penelitian tentang uji coliform dapat menekan biaya penelitiannya.
\end{abstract}

Kata kunci : bakteri coliform,bakteriologis,parafilm, plastik wrap

\begin{abstract}
This study aims to determine the use of plastic wrap as a substitute for parafilm in the practical of Environmental Microbiology to test bacteriological coliform bacteria against drinking water. This study used refill drinking water at refill shelters. One of the ingredients used for this examination was parafilm which function was to close the test tube so that the liquid in the tube did not spill when homogenization liquid process, by turning the tube in reverse. After the process done, the parafilm was reopened and discarded. The comparison to parafilm is that the availability and price of plastic wrap in the field is affordable and cheaper. The results of the estimation test on the sample was the similar amount of coliform obtained by using 3 colonies $/ 100 \mathrm{ml}$ for parafilm and plastic wrap. Moreover, a certainty test found the number of bacteria was 0 colony $/ 100 \mathrm{ml}$. The advantage of using this plastic wrap is the cost effeciency. By using the plastic wrap, researchers who use coliform tests can reduce the cost of their research.
\end{abstract}

Keywords: coliformbacteria, bacteriological, parafilm, plasticwrap.

\section{PENDAHULUAN}

Peralatan dan bahan untuk praktikum di Laboratorium sangat menunjang kegiatan di Laboratorium, baik dalam Pendidikan, penelitian dan pengabdian masyarakat. Jika salah satu dari keduanya tidak tersedia, maka akan menghambat pelaksanaan praktikum dan proses belajar mengajar di laboratorium. Dilaboratorium Mikrobiologi Lingkungan diadakan praktikum tentang pemeriksaan air secara bakteriologis, salah satunya pemeriksaan bakteri coliform pada air minum, air tanah dan air permukaan. Salah satu bahan yang digunakan yaitu parafilm yang berfungsi untuk menutup tabung reaksi agar cairan yang ada dalam tabung tidak keluar sewaktu dihomogenkan dengan cara membolak balikkan tabung.Parafilmtersedia dalam bentuk kemasan yang hanya dapat dibeli ditempat tertentu seperti toko bahan kimia dan tidak tersedia dalam skala eceran. Harga 1 pak / kemasan tersebut berkisar lima ratus ribu
rupiah.Dan ini menjadi kendala bagi mahasiswa yang melakukan penelitian. Oleh karena itu, diperlukan upaya untuk melakukan inovasi di laboratorium agar kebutuhan bahan untuk praktikum dan penelitian di Laboratorium Mikrobiologi Lingkungan ini dapat terpenuhi. Inovasi yang dilakukan adalah mengganti parafilm dengan plastik wrap yang harganya lebih murah dan mudah didapatkan di super market dan pasar.

\section{METODOLOGI}

\subsection{Waktu dan Tempat}

Penelitian ini dilakukan di Laboratorium Mikrobiologi Lingkungan pada tanggal 7 Juli 2017 sampai dengan 14 Juli 2017 dengan menggunakan sampel dari depot air minum isi ulang di daerah Pasar Baru Padang. 


\subsection{Alat dan Bahan}

Alat yang digunakan antara lain: tabung reaksi, tabung durham, pipet takar, lampu spiritus, jarum ose, gelas piala, erlenmeyer, autoklav, inkubator, neraca listrik dan lain lain.

Bahan yang digunakan antara lain : air minum galon, medium LB (LactoseBroth), BGLB (Brilliant Green LactoseBroth), alkohol 70\%, aquadest, kapas, aluminium foil, parafilm, dan plastikwrap.

\subsection{Tahapan penelitian}

\subsubsection{Pengambilan sampel}

Sampel air minum diambil dari air galon yang ada di daerah Pasar Baru Padang

\subsubsection{Pengenceran Sampel}

Pengenceran dilakukan dengan menggunakan aquadest steril. Menyiapkan tiga tabung pengenceran berisi $9 \mathrm{ml}$ aquadest steril dan memasukkan $1 \mathrm{ml}$ sampel pada tabung pertama merupakan pengenceran $10^{-1}$, selanjutnya dihomogenkan, lalu diambil $1 \mathrm{ml}$ dan dimasukkan kedalam tabung pengencer ke-2 yang merupakan pengenceran $10^{-2}$ selanjutnya dihomogenkan, lalu diambil $1 \mathrm{ml}$ dimasukkan kedalam tabung pengencer ke-3 yang merupakan pengenceran $10^{-3}$ (Cappuccinoand Sherman, 2002).

\subsubsection{Prosedurpemeriksaan}

\section{- Uji pendugaan}

Hasil pengenceran tersebut masing-masing dipipet sebanyak $1 \mathrm{ml}$ lalu dimasukkan kedalam tabung yang telah berisi medium Laktosa Broth (LB) yang dilengkapi dengan tabung Durham dalam posisi terbalik. Lalu tabung ditutup dengan parafilm atau plastik wrap dihomogenkan dengan cara membolakbalikkan tabung sehingga tidak terdapat udara dalam tabung Durham. Setelah itu lepaskan parafilm atau plastik wrap kembali dan tutup tabung dengan kapas. Pada pemeriksaan ini digunakan seri tiga tabung untuk masingmasing pengenceran sehingga jumlah semua tabung adalah 9 tabung. Kemudian semua tabung diinkubasikan dalam inkubator pada suhu $37^{\circ} \mathrm{C}$ selama 2 x 24 jam. Hasil yang positif ditandai dengan terbentuknya gas pada tabung Durham dan terjadinya perubahan warna pada medium (Cappuccinoand Sherman, 2002).

- Uji penegasan

Tabung yang memberikan hasil positif pada medium LactoseBroth(LB) ditanamkan 1-2 jarum ose kedalam tabung yang berisi $10 \mathrm{ml}$ medium BGLB(Brilliant Green LactoseBroth) yang didalamnya berisi Durham. Kemudian mulut tabung ditutup dengan parafilm lalu dihomogenkan. Kemudian diinkubasi dalam inkubator pada suhu $35^{\circ} \mathrm{C}$ selama 24- 48 jam. Dicatat hasil yang positif dengan ditandai adanya gas dalam Durham

Banyaknya kandungan bakteri dapat dilihat dengan menghitung tabung yang positif pada medium BGLB dan dibandingkan dengan tabel MPN (Depkes RI, 1977).

\section{HASIL DAN PEMBAHASAN}

Dari penelitian yang dilakukan didapatkan perbandingan hasil jumlah tabung yang positif pada media LB dengan menggunakan parafilm dan plastikwrap seperti dalam gambar berikut :
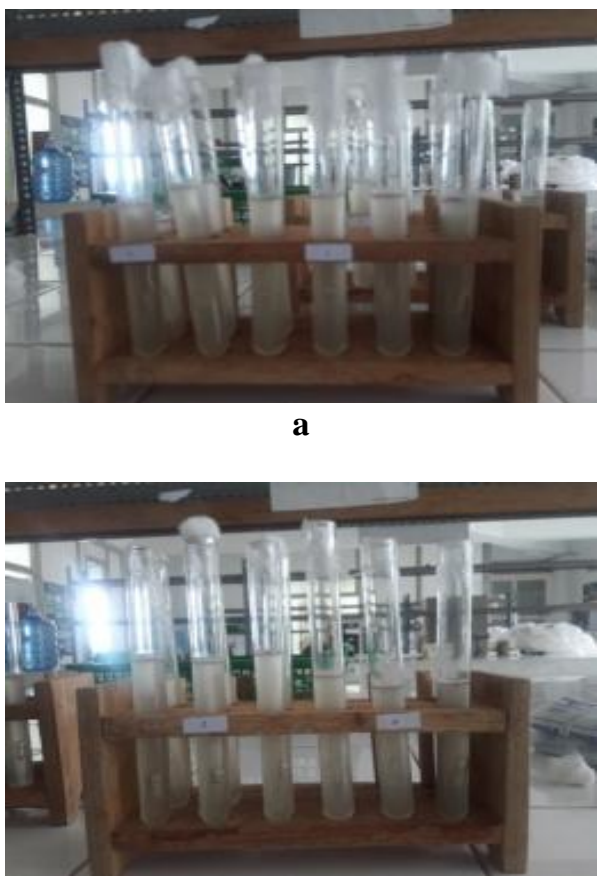

b

Gambar 3.1 a.) Tabung yang positif dengan parafilm., b.) Tabung yang positif dengan plastik wrap.

Uji pendugaan dengan menggunakan medium Laktose Broth(LB), dan memakai parafilm sebagai penutup mulut tabung di dapatkan tabung yang positif pada pengenceran $10^{-1}$, begitu juga dengan tabung yang memakai plastik wrap juga terdapat tabung yang positif pada pengenceran $10^{-1}$.

Hal ini menjelaskan bahwa tidak ada perbedaan hasil didapatkan dengan memakai parafilm ataupun memakai plastik wrap.

Tabel 3.1 Perbandingan jumlah tabung yang positif pada media LB dengan menggunakan parafilm dan plastik wrap

\begin{tabular}{ccccc}
\hline \multirow{2}{*}{$\begin{array}{c}\text { Jumlah tabung positif } \\
\text { pada pengenceran }\end{array}$} & \multirow{2}{*}{$\begin{array}{c}\text { MPN per } \\
100 \mathrm{ml}\end{array}$} & Keterangan \\
\cline { 1 - 3 } 10 & $10^{-1}$ & $10^{-2}$ & & \\
\hline 0 & 1 & 0 & 3 & Parafilm \\
\hline 0 & 1 & 0 & 3 & Plastik wrap \\
\hline
\end{tabular}

Berdasarkan Tabel 3.1 didapatkan tabung yang positif pada pengenceran $10^{-1}$ sebanyak 1 tabung 
dari 3 seri yang dilakukan, sedangkan pada pengenceran 10 dan $10^{-2}$ tidak terdapat tabung yang positif maka dilihat hasilnya pada tabel MPN, terdapat 3 koloni bakteri coliform.Hasil ini sama pada perlakuan dengan memakai parafilm maupun dengan memakai plastik wrap

Bakteri coliform adalah golongan bakteri yang merupakan campuran antara bakteri fekal dan bakteri non fekal. Prinsip penentuan bakteri coliform adalah adanya pertumbuhan bakteri coliform ditandai dengan terbentuknya gas pada tabung durham setelah diinkubasi pada media yang sesuai ( Harmita dan Radji, 2008 ).

Tabung yang menunjukkan hasil positif diuji lanjut dengan uji penegasan yaitu dengan memakai medium Brilliant Green LactoseBroth (BGLB) dan hasilnya terdapat dalam gambar berikut:

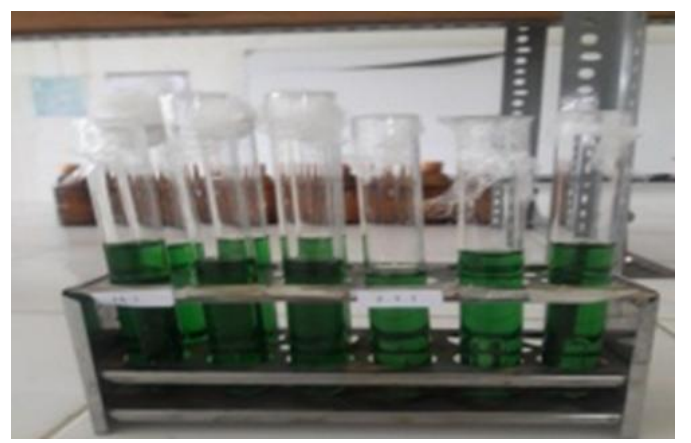

$\mathbf{a}$

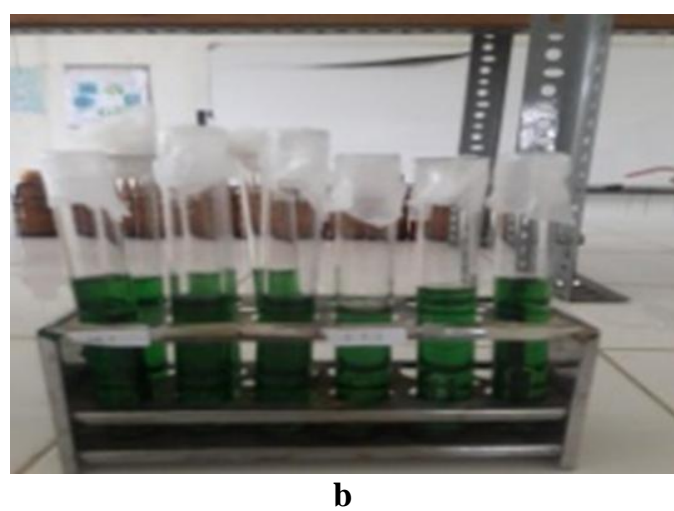

Gambar 3.2 a.) Tabung yang positif dengan parafilm.b.) Tabung yang positif dengan plastik wrap.

Uji penegasan dengan menggunakan medium Brilliant Green Laktose Broth(BGLB), dan memakai parafilm sebagai penutup tabung tidak terlihat tabung yang positif pada pengenceran 10 , $10^{-1}$ dan $10^{-2}$, begitu juga dengan tabung yang memakai plastik wrap juga tidak ada tabung yang positif pada pengenceran $10,10^{-1}$ maupun $10^{-2}$

Hal ini menjelaskan bahwa tidak ada perbedaan hasil didapatkan dengan memakai parafilm ataupun memakai plastik wrap.

Tabel 3.2 Perbandingan jumlah tabung yang positif pada media BGLB dengan menggunakan parafilm dan plastik wrap.

\begin{tabular}{ccccc}
\hline \multirow{2}{*}{$\begin{array}{c}\text { Jumlah tabung positif } \\
\text { pada pengenceran }\end{array}$} & \multirow{2}{*}{$\begin{array}{c}\text { MPN per } \\
100 \mathrm{ml}\end{array}$} & Keterangan \\
\cline { 1 - 3 } 10 & $10^{-1}$ & $10^{-2}$ & & \\
\hline 0 & 0 & 0 & 0 & Parafilm \\
\hline 0 & 0 & 0 & 0 & Plastik wrap
\end{tabular}

Berdasarkan Tabel 3.2 didapatkan semua tabung negatif pada pengenceran $10,10^{-1}$ dan $10^{-2}$ dari 3 seri yang dilakukan, maka dilihat hasilnya pada tabel MPN, tidak terdapat bakteri coliform. Hasil ini sama pada perlakuan dengan memakai parafilm maupun dengan memakai plastikwrap.

\section{KESIMPULAN}

Dari penelitian yang telah dilakukan dapat disimpulkan bahwa plastik wrap dapat digunakan sebagai pengganti parafilm dalam uji bakteriologis, dengan harga yang lebih terjangkau dan mudah didapatkan.

\section{DAFTAR PUSTAKA}

Cappuccino, J.G and N.Sherman, 2002, Microbiology a Laboratory manual. The Benjamin/Cumming Publishing Company, Inc.menlo Park, California.

Depkes RI, 1977,Metode pengambilan Contoh Air dan Pemeriksaan Bakteriologi Air, Seri B-1, Laboratorium Kesehatan Daerah Semarang.

Harmita dan Radji, M., 2008. Analisis Hayati. Penerbit Buku Kedokteran EGC. Jakarta. 